\title{
POTENCY OF HONEY AS ANTIBACTERIAL AGENT AGAINST MULTIPLE ANTIBIOTIC RESISTANT PATHOGENS EVALUATED BY DIFFERENT METHODS
}

\author{
${ }^{1}$ Mohamed Mustafa Aween, ${ }^{1}$ Zaiton Hassan, ${ }^{1}$ Nur Huda-Faujani, \\ ${ }^{1}$ Mohamed Muftah Emdakim and ${ }^{2}$ Belal Jamal Muhialdin \\ ${ }^{1}$ Faculty of Science and Technology, Universiti Sains Islam Malaysia (USIM), \\ 71800, Bandar Baru Nilai, Negeri Sembilan, Malaysia \\ ${ }^{2}$ Faculty of Food Science and Technology, Universiti Putra Malaysia (UPM), \\ UPM Serdang, 43400, Selangor, Malaysia
}

Received 2014-08-04; Revised 2014-10-15; Accepted 2014-10-20

\begin{abstract}
Honey is rich with complex natural components which could be useful as antibacterial agents or as preservative. Honey contains high concentration of sugars, low amount of water, high osmolality and often dark colour which influence its antibacterial activity. Disc diffusion, well method, micro dilution assay are methods commonly used to determine the antibacterial activity of honey. In this study, microtiter and microbial plate count were included to ascertain the potency of honey as antibacterial agent against multiple antibiotic resistant pathogenic bacteria (Staphylococcus aureus, Salmonella Typhimurium, Escherichia coli, Bacillus subtilis and Pseudomonas aeruginosa) with concentration of $0.2 \mathrm{~g} \mathrm{~mL}^{-1}$. Results found that well diffusion method tends to give higher inhibitory zone than disc diffusion method but there was no correlation among the bacteria was observed except for $S$. Typhimurium, E. coli $(\mathrm{R}=0.310,0.505$ and 0.316 , respectively). Nan photometer assay and microtiter plates assay showed comparable results with moderately strong correlation $\left(\mathrm{R}^{2}=0.681\right.$ and 0.767 , respectively) for $S$. aureus and $S$. typhimurium, but poor correlation was found for E. coli, B. subtilis and $P$. aeruginosa $\left(\mathrm{R}^{2}=0.441,0.308\right.$ and 0.383 , respectively). Determining the number of survivors by plating on agar after nanophotometer assay or microtiter plate assay had confirmed the effectiveness of honey as antimicrobial agent against target bacteria; which confirmed that honey has the potency to inhibit pathogens even at low concentration.
\end{abstract}

Keywords: Honey, Antibacterial Activity Assay, Multiple Antibiotic Resistant (MAR), Pathogenic Bacteria

\section{INTRODUCTION}

Honey not only a delicious food but are also known for its health and healing properties. Such concept is referred to in Surat El-Nahl, the Holy Quraan (verse 68 and 69). Honey has the ability to inhibit microorganisms including bacteria, spoilage fungi and yeast and viruses. The antibacterial effect of honey especially against Gram-positive bacteria are well documented (Molan,
1997; Bogdanov, 1997; Rozaini et al., 2004; Tan et al., 2009). Both bacteriostatic and bactericidal effects of honey have been reported for many strains especially pathogenic bacteria (Bogdanov et al., 2008). It is suggested that Manuka honey $(6 \% \mathrm{v} / \mathrm{v})$ can be used against Burkholderia cepacia which causes pulmonary infections and chronic granulomatous disease in urinary tract infections and wound infections in hospitalized patients (Cooper et al., 2000a; 2000b).

Corresponding Author: Mohamed Mustafa Aween, Faculty of Science and Technology, Universiti Sains Islam Malaysia (USIM), 71800, Bandar Baru Nilai, Negeri Sembilan, Malaysia 
Honey has significant amount of glucose oxidase, catalase, ascorbic acid, flavonoids, phenolic acids, carotenoid derivatives, organic acids, Maillard reaction products, amino acids and proteins that contribute to its functional properties (Bogdanov et al., 2008; Perez et al., 2007). Honey contains cinnamic acid, antioxidant agent and some flavonoids which have been approved for antibacterial applications (Rahman et al., 2010). Mohammed (2010) reported that Malaysian honey have antioxidant properties. The antioxidants compounds in honey may play a positive role in food safety beyond food preservation (Taormina et al., 2001).

In Malaysia, research on honey has focused on different aspects. Tualang honey was reported to be effective for wound healing and wound burn management (Nasir et al., 2010) and the effects of different types of honey on tensile strength evaluation of burn wound tissue healing were evaluated by Rozaini et al. (2004). The types of phenolic acidsin Malaysian honey were suggested to be responsible for the antibacterial properties (Aljadi and Yusoff, 2003) while other local Malaysian honey showed antimicrobial activity on some human pathogens (Tumin et al., 2005; Hassanain et al., 2010; Zainol et al., 2013). Propolis of Malaysian honey inhibited the growth of Staphylococcus aureus and Escherichia coli as reported by Rahman et al. (2010). Honey of Malaysia, Libya, New Zealand and Saud Arabia contain lactic acid bacteria with antibacterial activity against selected Multiple Antibiotic Resistant (MAR) Gram-positive bacteria and Gram-negative bacteria (Aween et al., 2012a; 2012b).

Two methods that are commonly used to evaluate the antibacterial activity are disc diffusion method (Bauer et al., 1966) and well diffusion (Perez et al., 1990). Since honey is a complex of substances, these methods may not reflect the potency of honey as antibacterial agent. Therefore, other methods namely nanophotometer assay, microtiter plates and microbial plate count methods were included in this study in an attempt to evaluate the effectiveness of the methods for determination of the antibacterial activity of honey on multiple antibiotic resistant pathogenic bacteria.

\section{MATERIALS AND METHODS}

\subsection{Honey Samples}

Nine samples of honey were obtained from different sources and coded as follows: Tualang honey (H026) and Acacia honey (H030, H031 and H032) from Malaysia, AlSeder (H025), Kharoob (H028) and Hannon Honey (H020) from Libya and Manuka Honey 5+ (H027) and 10+ (H035) from New Zealand. All samples were kept in glass bottles and stored at room temperature before experiment.

\subsection{Honey Samples Preparation}

Amount of honey used was based on the lowest concentration that showed antibacterial activity. Honey samples $\left(0.2 \mathrm{~g} \mathrm{~mL}^{-1}\right.$ deionized water $)$ were prepared and all honey samples were heated at $70^{\circ} \mathrm{C}$ for $10 \mathrm{~min}$ using water bath and filtered using $0.45 \mu \mathrm{L}$ filters and then kept at $4{ }^{\circ} \mathrm{C}$ for further study. Heating removed $\mathrm{H}_{2} \mathrm{O}_{2}$ and destroyed any contaminating microorganisms that may be present in honey samples.

\subsection{Cultures of Pathogenic Bacteria}

The pathogenic bacteria used in this study were $S$. aureus, S. Typhimurium, E. coli, B. subtilis and $P$. Aeruginosa obtained from Microbiology Laboratory Faculty of Science and Technology, Universiti Sains Islam Malaysia (USIM), Malaysia. The bacteria were grown on nutrient agar (Oxoid, UK) and nutrient broth (Oxoid, UK) at $37^{\circ} \mathrm{C}$ for $24 \mathrm{~h}$ and then kept at $4^{\circ} \mathrm{C}$ before further experiments.

\subsection{Antibiotic Resistant Test of Target Bacteria}

The target bacteria were tested for their resistant to antibiotics using disc diffusion method as described by Bauer et al. (1966). The antibiotics used were vancomycin $(5 \mu \mathrm{m})$, cephalothin $(30 \mu \mathrm{m})$, nalidixic acid $(30 \mu \mathrm{m})$, Gentamycin $(10 \mu \mathrm{m})$, streptomycin $(10 \mu \mathrm{m})$, tetracycline $(30 \mu \mathrm{m})$, bacitracine $(10 \mu \mathrm{m})$, penicillin $\mathrm{G}$ $(10 \mu \mathrm{m})$, chloramphenicol $(30 \mu \mathrm{m})$ and polymyxin $\mathrm{B}$ $(300 \mu \mathrm{m})$ (Sigma). The selection of antibiotics in this study was based on the common antibiotics used in medical practice and health therapy. Mean, standard deviation and MAR index were calculated for all target bacteria (Subramani and Vignesh, 2012).

\subsection{Antibacterial Activity of Honey Samples using Disc Diffusion Method}

Antibacterial activity of selected honey samples were determined by disc diffusion method on Nutrient Agar (NA) agar (Oxoid, UK) (Bauer et al., 1966). The pathogenic bacteria cultures were swabbed on NA agar plates. Discs were overlaid with tested honey samples overnight and then dried at $45^{\circ} \mathrm{C}$ for $24 \mathrm{~h}$ using drier oven (BINDER, Germany). Discs were placed on swabbed agars and incubated at $37^{\circ} \mathrm{C}$ for $24 \mathrm{~h}$. Inhibition zone diameter was carefully measured and the results were expressed in millimetre. This experiment was done in duplicate and mean with standard deviation were calculated. 


\subsection{Antibacterial Activity of Honey Samples using well Diffusion Method}

The well diffusion method for antibacterial activity of honey was determined following the method of Perez et al. (1990) with slight modifications. Honey samples were prepared with concentration of $0.2 \mathrm{~g} \mathrm{~mL}^{-1}$ $(\mathrm{w} / \mathrm{v})$ using deionized water. Overnight culture of pathogenic bacteria in nutrient broth (Oxoid, UK) was prepared. Nutrient agar was prepared and once its temperature reached $40^{\circ} \mathrm{C}, 1 \%$ of pathogenic bacteria $\left(10^{9} \mathrm{CFU} / \mathrm{ml}\right)$ was added and mixed carefully. Amount of $25 \mathrm{~mL}$ of the nutrient agar with $1 \%$ of pathogenic bacteria was poured to petri dish plates and left under a laminar flow until the plates dried. Wells of $8 \mathrm{~mm}$ diameter was made using a sterile cork-borer with $8 \mathrm{~mm}$ diameter and the base of the wells were covered with nutrient agar (Oxoid, UK) and left to dry at room temperature. After that, $200 \mu \mathrm{L}$ of prepared honey samples were poured to the wells individually and kept at $37^{\circ} \mathrm{C}$ for $24 \mathrm{~h}$. The results were expressed by measuring the zones around the wells after diminution the well size. The experiment was done in duplicate and mean with standard deviation were calculated.

\subsection{Antibacterial Activity of Honey Samples using Nanophotometer Assay}

In Nanophotometer method, concentration of $0.2 \mathrm{~g}$ $\mathrm{mL}^{-1}$ honey samples were prepared using deionized water. Pathogenic bacteria were inoculated to Nutrient broth (Oxoid, UK) and kept at $37^{\circ} \mathrm{C}$. $1 \mathrm{~mL}$ of each honey sample was poured to $1 \mathrm{~mL}$ of pathogenic bacteria $\left(10^{6}\right.$ $\mathrm{CFU} / \mathrm{ml}$ ) in micro-titer plates and kept at $37^{\circ} \mathrm{C}$ for $24 \mathrm{~h} .1$ $\mathrm{mL}$ of each honey sample with $1 \mathrm{~mL}$ of nutrient broth without pathogenic bacteria was used as negative control and $1 \mathrm{~mL}$ of broth with pathogens with $1 \mathrm{~mL}$ of broth was used as positive control. The reading was determined as bacteria cells using Nanophotometer (IMPLEN, Germany) at wavelength of $600 \mathrm{~nm}$. The results then were interpreted using the following formula:

Percentage of inhibition $=[($ Positive control absorbanceSample absorbance)/Positive Control absorbance] $\times 100$

\subsection{Antibacterial Activity of Honey Samples using Microtiter Plates}

Each honey sample was tested against the selected pathogenic bacteria in microtiter plate assay, following the method of Magnusson and Schnurer (2001) with some modifications. $100 \mu \mathrm{L}$ of nutrient broth (NB) containing $10^{6}$ pathogenic bacteria/ml were placed in the 96 wells plate and $150 \mu \mathrm{L}$ honey samples $(0.2 \mathrm{~g}$ $\mathrm{mL}^{-1}$ ) were poured into the wells. The plates were incubated at $37^{\circ} \mathrm{C}$ for $24 \mathrm{~h}$. Optical density of bacterial growth was measured at $630 \mathrm{~nm}$ using Elisa plate reader (BIOTEK, USA). Honey with Nutrient Broth (NB) without bacteria was used as negative control and Nutrient Broth (NB) with pathogenic bacteria was used as positive control. The results then were interpreted using the following formula:

Percentage of inhibition $=(+$ Control absorbance-Sample absorbance $) /+$ Control absorbance $) \times 100$

\subsection{Antibacterial Activity of Honey Samples using Total Plate Count Assay}

Antibacterial activity of selected honey samples were determined by plate count method on Nutrient Agar (NA) (OXOID) following Aween et al. (2012b) with some modifications. $100 \mu \mathrm{L}$ of overnight pathogenic bacteria culture in NB were added to $100 \mu \mathrm{L}$ of honey sample and kept at $37^{\circ} \mathrm{C}$ for $24 \mathrm{~h}$. After that, $10 \mu \mathrm{L}$ of the mixture were spread on NA and incubated at $37^{\circ} \mathrm{C}$ for $24 \mathrm{~h}$. Pathogenic bacteria in NB was used as positive control and honey sample with NB as negative control. The results were taken by counting the number of pathogenic bacteria colonies on NA plates after $24 \mathrm{~h}$ of incubation and expressed as $\log _{10} \mathrm{CFU} / \mathrm{ml}$. The enumeration of bacteria on plates followed standard microbiological procedure.

\subsection{Statistical Analysis}

All data were analyzedusingMinitab16 system to calculate the mean, standard division and percentage of inhibition. The correlation was carried out between the methods (disk diffusion method versus well diffusion method and microtiter plates versus nanophotometer) and the bacteria tested were determined ( $\mathrm{R}=<0$ no correlation, $\mathrm{R}=0-0.7$ poor correlation and $\mathrm{R}=0.7-1$ strong correlation).

\section{RESULTS}

\subsection{Antibiotic Resistant of Selected Target Bacteria}

The target bacteria showed high resistance to several antibiotics tested. The diameter of inhibition zone varies between 0 and $29 \mathrm{~mm}$ (Table 1). All target bacteria were not inhibited by Bacitracin, Polymyxin B, Penicillin G, Vancomycin and Streptomycin. However, S. aureus were totally resistant to polymyxin B, while $S$. 
Typhimurium and B. subtilis were resistant tobacitracin, tetracycline, penicillin $\mathrm{G}$, vancomycin, naladixic acid and Chloramphenicol. E. coli were resistant to Bacitracin, Gentamycin, Penicillin G and Vancomycin. Bacitracin, Tetracycline, Penicillin G, Vancomycin and Chloramphenicol were not effective against $P$. aeruginosa. MAR index was from 11 to $88 \%, S$. Typhimurium and B. subtilisshowed the highest MAR index percentage (88\%) compared to E. coli $(55 \%), P$. aeruginosa $(66 \%)$ and $S$. aureus $(11 \%)$.

\subsection{Antibacterial Activity of Honey Samples using Disc Diffusion Method}

All the ninehoney samples showed variable inhibitory activities against the target bacteria by the disc diffusion method (Table 2). The inhibitory activity was significantly $(\mathrm{p}<0.5)$ affected by the type of bacteria used but not with honey samples. $P$. aeruginosa was greatly inhibited by all honey samples as shown by inhibitory zone greater than $10.5 \pm 4.94$ mm except $\mathrm{H} 032$ which was less than $(7.5 \pm 0.70 \mathrm{~mm})$. While E. coli and S. Typhimurium were inhibited but to a lesser extent (Table 2). Tualang honey (H026) from Malaysia showed the highest inhibitory activity against $S$. aureus, $S$. Typhimurium and B. subtilis $(20.00 \pm 1.41, \quad 14.00 \pm 4.24$ and $17.00 \pm 0.00 \mathrm{~mm}$ respectively), Acacia honey (H031) from Malaysia showed the highest inhibitory zone of $18.50 \pm 3.53$ and $17.00 \pm 0.00 \mathrm{~mm}$ against E. coli and B. subtilis, while against $P$. aeruginosa Al-Seder honey (H025) from Libya showed the highest activity.

Table 1. The antibacterial activities of selected antibiotics against target bacteria ${ }^{a}$

\begin{tabular}{|c|c|c|c|c|c|}
\hline \multirow[b]{2}{*}{ Antibiotics } & \multicolumn{5}{|c|}{ Target bacteria } \\
\hline & S. aureus & S. Typhimurium & E. coli & B. subtilis & P. aeruginosa \\
\hline Bacitracin $(10 \mu \mathrm{g})$ & $6.50 \pm 0.70$ & $0.00 \pm 0.00$ & $0.00 \pm 0.00$ & $0.00 \pm 0.00$ & $0.00 \pm 0.00$ \\
\hline Gentamycin $(120 \mu \mathrm{g})$ & $11.00 \pm 0.00$ & $14.50 \pm 0.70$ & $0.00 \pm 0.00$ & $13.00 \pm 0.00$ & $13.00 \pm 0.00$ \\
\hline Tetracycline $(10 \mu \mathrm{g})$ & $13.50 \pm 2.12$ & $0.00 \pm 0.00$ & $8.00 \pm 5.65$ & $0.00 \pm 0.00$ & $2.50 \pm 2.12$ \\
\hline Naladixic acid $(30 \mu \mathrm{g})$ & $8.50 \pm 0.70$ & $0.00 \pm 0.00$ & $18.00 \pm 0.00$ & $0.00 \pm 0.00$ & $17.00 \pm 0.00$ \\
\hline Polymyxin B $(300 \mu \mathrm{g})$ & $0.00 \pm 0.00$ & $4.00 \pm 0.00$ & $4.00 \pm 0.00$ & $4.00 \pm 0.00$ & $4.00 \pm 0.00$ \\
\hline Penicillin $\mathrm{G}(5 \mu \mathrm{g})$ & $29.00 \pm 0.00$ & $0.00 \pm 0.00$ & $0.00 \pm 0.00$ & $0.00 \pm 0.00$ & $0.00 \pm 0.00$ \\
\hline Vancomycin $(5 \mu \mathrm{m})$ & $6.00 \pm 0.00$ & $0.00 \pm 0.70$ & $0.00 \pm 0.00$ & $0.00 \pm 0.00$ & $0.00 \pm 0.00$ \\
\hline Streptomycin $(10 \mu \mathrm{m})$ & $6.00 \pm 0.00$ & $3.00 \pm 0.00$ & $8.50 \pm 0.70$ & $3.00 \pm 0.00$ & $7.50 \pm 0.70$ \\
\hline Chloramphenicol $(30 \mu \mathrm{g})$ & $15.00 \pm 2.82$ & $0.00 \pm 0.00$ & $18.50 \pm 4.94$ & $0.00 \pm 0.00$ & $0.00 \pm 0.00$ \\
\hline MAR index \% & 11 & 88 & 55 & 88 & 66 \\
\hline
\end{tabular}

${ }^{\mathrm{a}}$ Diameter of inhibition zone around the discs (mm)

Table 2. Growth inhibition zone of target bacteria by honey samples by disc diffusion method ${ }^{\text {a }}$

\begin{tabular}{|c|c|c|c|c|c|}
\hline \multirow[b]{2}{*}{ Honey sample } & \multicolumn{5}{|c|}{ Target bacteria } \\
\hline & S. aureus & S. Typhimurium & E. coli & B. subtilis & P. aeruginosa \\
\hline H020 & $16.50 \pm 0.70$ & $11.50 \pm 4.94$ & $13.00 \pm 4.24$ & $15.50 \pm 0.70$ & $15.00 \pm 0.00$ \\
\hline H025 & $19.50 \pm 0.70$ & $11.50 \pm 3.53$ & $10.50 \pm 2.12$ & $15.50 \pm 0.70$ & $17.00 \pm 0.00$ \\
\hline H026 & $20.00 \pm 1.41$ & $14.00 \pm 4.24$ & $13.50 \pm 3.53$ & $17.00 \pm 0.00$ & $16.00 \pm 0.00$ \\
\hline H027 & $17.00 \pm 0.00$ & $11.50 \pm 2.12$ & $11.00 \pm 1.41$ & $15.50 \pm 0.70$ & $16.00 \pm 0.00$ \\
\hline H028 & $17.00 \pm 1.41$ & $10.50 \pm 3.53$ & $11.50 \pm 3.53$ & $14.00 \pm 0.00$ & $15.00 \pm 0.00$ \\
\hline H030 & $19.00 \pm 0.00$ & $13.50 \pm 2.12$ & $15.00 \pm 2.82$ & $15.50 \pm 0.70$ & $14.50 \pm 3.53$ \\
\hline H031 & $16.50 \pm 3.53$ & $12.00 \pm 1.41$ & $18.50 \pm 3.53$ & $17.00 \pm 0.00$ & $12.50 \pm 4.94$ \\
\hline H032 & $17.00 \pm 1.41$ & $11.00 \pm 1.41$ & $13.50 \pm 2.12$ & $16.50 \pm 0.70$ & $7.50 \pm 0.70$ \\
\hline H035 & $18.00 \pm 1.41$ & $11.50 \pm 3.53$ & $14.50 \pm 2.12$ & $15.50 \pm 0.70$ & $10.50 \pm 4.94$ \\
\hline
\end{tabular}

${ }^{\mathrm{a}}$ Diameter of growth inhibitory zone was measured in mm after $24 \mathrm{~h}$ incubation at $37^{\circ} \mathrm{C}$ 


\subsection{Antibacterial Activity of Honey Samples using well Diffusion Method}

In well diffusion method, all honey samples from different sources showed inhibitory activity against all the target pathogenic bacteria; however, in the current study the degree of inhibition was affected by type of bacteria; the growth inhibitory zonevaries between 15.5 and $27.5 \mathrm{~mm}$ (Table 3 and Fig. 1). Among the bacteria evaluated, $S$. aureus was easily inhibited by all the tested honey samples, while E. coli was the most difficult to be inhibited. Growth of $S$. aureus was easily inhibited by Hannon honey, Libya (H020), Acacia honey, Malaysia (H031), Acacia honey, Malaysia (H032) and Manuka honey, New Zealand (H027) with inhibitory zone of 27.50, 25.00, 25.00 and $25.50 \mathrm{~mm}$, respectively (Table 3 and Fig. 1). Growth of $S$. Typhimurium and B. subtilis were moderately inhibited by all honey samples with inhibitory zone between 15.50 to $19.50 \mathrm{~mm}$. All honey samples also inhibited $P$. aeruginosa (16.00 to $18.50 \mathrm{~mm}$ inhibitory zone). Libyan honey Hannon honey (H020) showed the highest inhibitory activity against all tested pathogenic bacteria (18.50 to 27.50) except against $E$. coli $(15.00 \mathrm{~mm})$, while Acacia honey (H032) was effective against $S$. aureus $(25.00 \mathrm{~mm}), S$. Typhimurium $(18.00 \mathrm{~mm})$ and E. coli $(17.00 \mathrm{~mm})$.

\subsection{Antibacterial Activity of Honey Samples using Nanophotometer Assay}

In Nanophotometer assay the survival of target bacteria was determined using nanophotometer and the results were expressed as percentage inhibition from survival $(\mathrm{CFU} / \mathrm{ml})$ of the bacteria after treatment with honey (Table 4). The percentage of inhibition of all honey samples ranged from 13.17 to $100 \%$. AlSeder honey (H025) showed total inhibition (100\%) against $S$. aureus, E. coli and $P$. aeruginosa; Acacia honey (H030) showed inhibitory activity against $S$. aureus and S. Typhimurium (100 and 99.09\%). $S$. aureus and $E$. coli were easily inhibited by all tested honey samples with percentage of 94.26 to 100 and 83.36 to 100 , respectively. All samples of honey showed inhibitory activity against $P$. aeruginosa except H031 (13.17\%).

Table 3. Growth inhibition zone of target bacteria by honey samples using well method

\begin{tabular}{|c|c|c|c|c|c|}
\hline \multirow[b]{2}{*}{ Honey sample } & \multicolumn{5}{|c|}{ Target bacteria } \\
\hline & S. aureus & S. Typhimurium & E. coli & B. subtilis & P. aeruginosa \\
\hline H020 & $27.50 \pm 0.70$ & $19.00 \pm 1.41$ & $15.00 \pm 2.82$ & $19.50 \pm 00.70$ & $18.50 \pm 2.12$ \\
\hline H025 & $22.50 \pm 0.70$ & $16.50 \pm 0.70$ & $15.50 \pm 0.70$ & $17.50 \pm 0.70$ & $16.00 \pm 0.00$ \\
\hline H026 & $24.50 \pm 0.70$ & $18.00 \pm 1.41$ & $16.50 \pm 0.70$ & $17.50 \pm 0.70$ & $16.00 \pm 0.00$ \\
\hline H027 & $25.50 \pm 2.12$ & $17.00 \pm 2.12$ & $14.00 \pm 0.00$ & $19.00 \pm 0.00$ & $17.50 \pm 0.70$ \\
\hline H028 & $24.50 \pm 3.53$ & $15.50 \pm 0.70$ & $14.00 \pm 0.00$ & $18.00 \pm 0.00$ & $16.50 \pm 0.70$ \\
\hline H030 & $23.50 \pm 0.70$ & $17.50 \pm 0.70$ & $15.00 \pm 0.00$ & $18.50 \pm 0.70$ & $16.00 \pm 0.00$ \\
\hline H031 & $25.00 \pm 0.70$ & $17.50 \pm 0.70$ & $16.50 \pm 0.70$ & $17.50 \pm 0.70$ & $16.00 \pm 0.00$ \\
\hline H032 & $25.00 \pm 0.00$ & $18.00 \pm 0.00$ & $17.00 \pm 0.00$ & $18.00 \pm 1.41$ & $16.00 \pm 0.00$ \\
\hline H035 & $24.00 \pm 0.00$ & $18.50 \pm 0.70$ & $15.00 \pm 0.70$ & $17.50 \pm 0.70$ & $16.00 \pm 0.00$ \\
\hline
\end{tabular}

${ }^{\mathrm{a}}$ Diameter of growth inhibitory zone was measured in $\mathrm{mm}$ after $24 \mathrm{~h}$ incubation at $37^{\circ} \mathrm{C}, \pm=\mathrm{SD}$

Table 4. Percentage of inhibition of target bacteria by honey samples using Nanophotometer assay ${ }^{\mathrm{a}}$

\begin{tabular}{|c|c|c|c|c|c|}
\hline \multirow[b]{2}{*}{ Honey sample } & \multicolumn{5}{|c|}{ Target bacteria (\% inhibition) } \\
\hline & S. aureus & S. Typhimurium & E. coli & B. subtilis & P. aeruginosa \\
\hline $\mathrm{H} 020$ & 94.26 & 78.47 & 83.36 & 82.18 & 93.92 \\
\hline $\mathrm{H} 025$ & 100.00 & 83.68 & 100.00 & 92.78 & 100.00 \\
\hline H026 & 100.00 & 93.59 & 99.82 & 97.81 & 99.25 \\
\hline H027 & 99.15 & 82.28 & 90.03 & 84.67 & 96.75 \\
\hline H028 & 99.46 & 87.18 & 99.17 & 87.36 & 97.54 \\
\hline H030 & 100.00 & 99.09 & 97.18 & 96.06 & 96.93 \\
\hline H031 & 97.92 & 79.57 & 94.84 & 95.82 & 13.17 \\
\hline H032 & 98.40 & 88.08 & 96.92 & 95.82 & 93.27 \\
\hline H035 & 99.15 & 94.09 & 92.11 & 90.64 & 70.40 \\
\hline
\end{tabular}

${ }^{\mathrm{a}}$ Percentage of inhibition $=[(+$ Control absorbance - Sample absorbance $) /+$ Control absorbance $] \times 100$ 

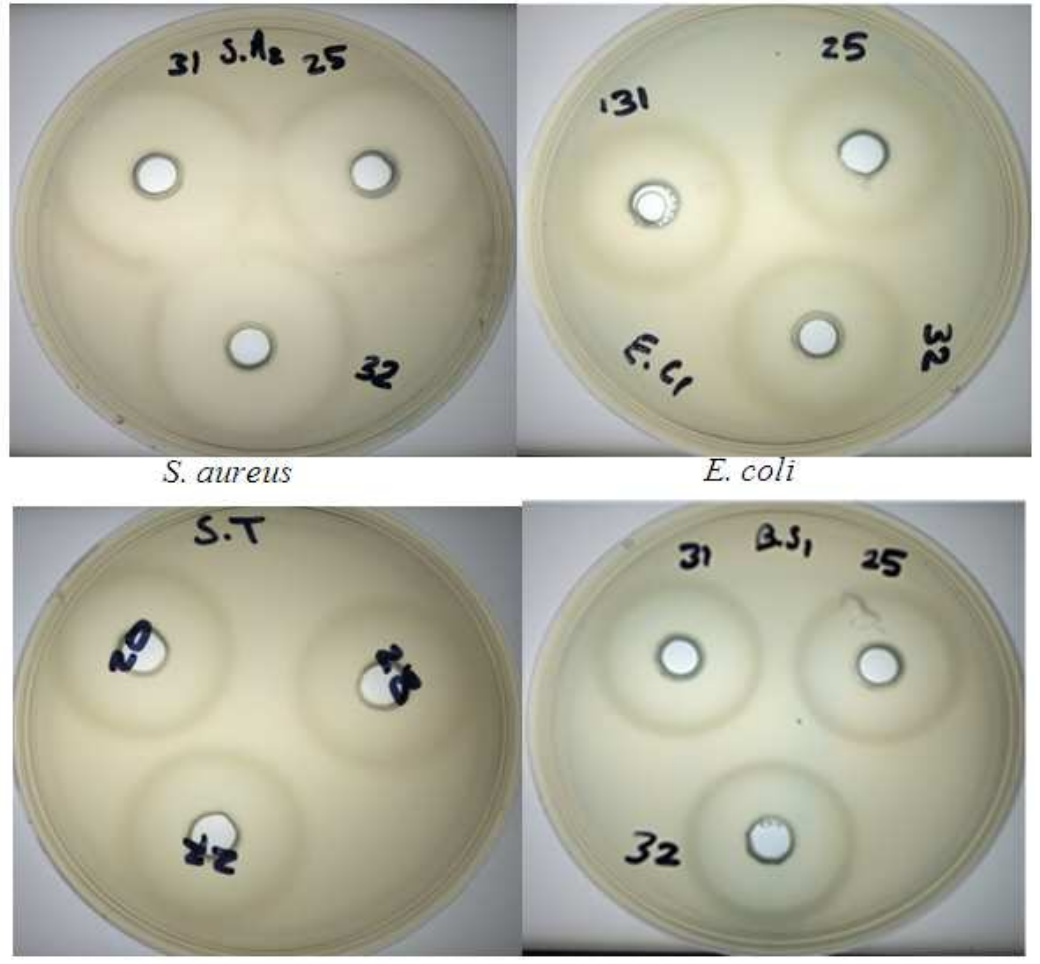

S. Typhimurium

B. subtilis

Fig. 1. Growth inhibition zone of honey samples against pathogenic bacteria by well method at $37^{\circ} \mathrm{C}$ after $24 \mathrm{~h}$ of incubation

Table 5. Percentage of inhibition of target bacteria by honey samples using microtiter plates

\begin{tabular}{|c|c|c|c|c|c|}
\hline \multirow[b]{2}{*}{ Honey sample } & \multicolumn{5}{|c|}{ Target bacteria (\% inhibition) } \\
\hline & S. aureus & S. Typhimurium & E. coli & B. subtilis & $P$. aeruginosa \\
\hline H020 & 70.14 & 74.63 & 70.93 & 74.44 & 64.04 \\
\hline H025 & 98.48 & 86.52 & 85.43 & 89.17 & 93.73 \\
\hline H026 & 100.00 & 92.38 & 90.69 & 95.22 & 89.08 \\
\hline H027 & 99.33 & 89.22 & 96.89 & 96.25 & 97.49 \\
\hline H028 & 80.37 & 85.06 & 83.28 & 85.17 & 74.50 \\
\hline H030 & 89.00 & 92.32 & 88.47 & 91.02 & 80.05 \\
\hline H031 & 70.61 & 77.15 & 76.12 & 74.14 & 73.25 \\
\hline H032 & 98.48 & 93.79 & 93.54 & 95.58 & 87.56 \\
\hline $\mathrm{H} 035$ & 97.53 & 89.45 & 82.52 & 86.40 & 75.76 \\
\hline
\end{tabular}

${ }^{\mathrm{a}}$ Percentage of inhibition $=[(+$ Control absorbance - Sample absorbance $) /+$ Control absorbance $] \times 100$

\subsection{Antibacterial Activity of Honey Samples using Microtiter Plates}

Microtiter plates measures growth of bacteria by turbidity at $\mathrm{OD}_{630}$. All tested honey samples exhibited high inhibitory activity against all target pathogenic bacteria. Percentage of inhibition of target bacteria ranged from 60 to $100 \%$ by all honey samples within 24 $\mathrm{h}$ of incubation (Table 5). The growth of $S$. aureus was totally inhibited (100\%) by Tualang honey (H026), while Acacia honey (H032) showed the highest inhibitory activity against $S$. Typhimurium $(93.79 \%)$. The lowest activity was obtained from Hannon honey (H020) against all tested pathogens (64.04-74.63\%). 
Table 6. Growth inhibition of target bacteria by honey samples using total plate count method ${ }^{\text {a }}$ Target bacteria (CFU/ml)

\begin{tabular}{llllll} 
Honey sample & S. aureus & S. Typhimurium & E. coli & B. subtilis & P. aeruginosa \\
\hline H020 & $<10$ (est.) & $10^{5}$ & $<10$ (est.) & $10^{5}$ & $10^{5}$ \\
H025 & $10^{5}$ & $10^{5}$ & $<10$ (est.) & $10^{5}$ & $<10$ (est.) \\
H026 & $<10$ (est.) & $<10$ (est.) & $<10$ (est.) & $<10$ (est.) & $<10$ (est.) \\
H027 & $10^{5}$ & $10^{5}$ & $<10$ (est.) & $10^{5}$ & $10^{5}$ \\
H028 & $<10$ (est.) & $10^{5}$ & $<10$ (est.) & $<10$ (est.) & $<10$ (est.) \\
H030 & $<10$ (est.) & $<10$ (est.) & $<10$ (est.) & $<10$ (est.) & $10^{3}$ \\
H031 & $10^{3}$ & $10^{3}$ & $10^{5}$ & $10^{3}$ & $10^{5}$ \\
H032 & $<10$ (est.) & $<10$ (est.) & $<10$ (est.) & $<10$ (est.) & $10^{5}$ \\
H035 & $<10$ (est.) & $10^{3}$ & $10^{5}$ & $10^{5}$ & $10^{5}$ \\
+ Control & $10^{16}$ & $10^{15}$ & $10^{15}$ & $10^{15}$ & $10^{16}$ \\
\hline
\end{tabular}

${ }^{\mathrm{a}} 10$ : Number of colonies

\subsection{Antibacterial Activity of Honey Samples using total Plate Count Assay}

Survival of target bacteria as evaluated by plate count method was significantly affected by honey samples and by type of bacteria (Table 6). Tualang Honey (H026) had inhibited all tested pathogenic bacteria, followed by H030 and Acacia honey (H032) which inhibited all tested bacteria except $P$. aeruginosa. Growth of $E$. coli was totally inhibited by all honey samples except Acacia honey (H031) and Manuka honey (H035). S. aureus was not sensitive to Al-Seder honey (H025) and Manuka honey (H027), but inhibited by all the others. Hannon honey (H020) and Al-Seder honey (H025) were not active against $S$. Typhimurium and B. subtilis. Generally, all the honey samples showed good antibacterial activity against tested pathogenic bacteria compared to the positive control as evaluated by this method.

\section{DISCUSSION}

The occurrence of MAR bacterial strains is a public health concerns due to the bacteria are not easily killed by common antibiotics that normally used for health therapy. Some strains of Staphylococcus species were resistant to several antibiotics (Salvatore et al., 2010); $S$. aureus was resistant to ampicillin, kanamycin and oxytetracycline. The $S$. aureus used in this study demonstrated low MAR index $11 \%$ compared E. coli and $P$. aeruginosa with 55 and $66 \%$, respectively. $S$. Typhimurium and B. subtilis showed highest MAR index (88\%) compared to other tested bacteria.Similarly, multiple antibiotic resistant bacteria was shown by several tested pathogens including S. Typhimurium ATCC13311 that was resistant to 10 antibiotics especially to bacitracin, cephalothin, penicillin G, vancomycin and strepromycin; E. coli ATCC25922 was resistant to bacitracin, penicillin $G$ and vancomycin observed by Aween et al. (2012b).

The presence of multiple resistance pathogenic bacteria has led to the investigation of natural effective alternatives to common antibiotics used in medical practice and health therapy. The results of presence study showed that honey available in Malaysia can be used as antibacterial agent to prevent and control infections which are caused by the pathogenic bacteria. Five different methods were used to evaluate the antibacterial activity of different honey samples and the results showed no correlation $(\mathrm{R}=<0)$ between disc diffusion method and well diffusion methodexcept for $S$. Typhimurium, E. coli and P. aeruginosa which was poor $(\mathrm{R}=0.310,0.505$ and 0.316 , respectively).Well diffusion method was more suitable method for detecting the susceptibility of bacteria to antibacterial substances compared to disc diffusion. In contrast, the disc diffusion method is mainly used as a qualitative test for detecting the susceptibility of bacteria to antimicrobial substances (Mandal and Mandal, 2011). Disc diffusion is based on the ability of molecules to diffuse into the agar; while well method, nanophotometer assay and microtiter plates allowed direct contact of the bacterial surfaces to the compounds. It was also observed that there was correlation $(\mathrm{R}=0.308$ to 0.767$)$ between nanophotometer assay and microtiter plates method.

Earlier reports showed that Egyptian clover honey tested for its antibacterial effect against antibiotic resistant strains of E. coli and S. Typhimurium using disc diffusion method was more pronounced on E. coli than S. Typhimurium (Badawy et al., 2004); the Zone Diameter of Inhibition (ZDI) of different honey samples against $E$. coli was 12 to $24 \mathrm{~mm}$ and $S$. Typhimurium was 0 to $20 \mathrm{~mm}$. Manuka honey has been demonstrated to be effective against several human pathogens $S$. aureus, $S$. 
Typhimurium, E. coli and E. aeruginosa using agar diffusion method (Lusby et al., 2005; Visavadia et al., 2006). The potency of six varieties of honey from different regions in Algeria were determined against $P$. aeruginosa using disc diffusion method and results showed that Sahara honey have inhibitory activity against tested pathogens and the authors suggested that Sahara honey could be used to manage the wounds and burns infected by $P$. aeruginosa (Boukraa and Niar, 2007). Recently, Boorn et al. (2010) tested eleven samples of stingless bee honey and the antibacterial activity was assessed using agar diffusion method which showed inhibitory activity against Gram-negative and Gram-positive bacteria including $S$. aureus, $S$. epidermidis, S. Typhimurium, E. coli and P. aeruginosa. Nilgiris honeys showed Zone Diameter of Inhibition (ZDIs) of 20-21 mm for $S$. aureus, 15-16 mm for $P$. aeruginosa and 13-14 mm for E. coli (Rajeswari et al., 2010). RS and Manuka honeys killed B. subtilis, E. coli, $P$. aeruginosa and $S$. aureus after $24 \mathrm{~h}$ of incubation (Kwakman et al., 2011) using disc diffusion method. In this study using disc diffusion method, it was observed that Tualang and Acacia honeys showed higher inhibitory activity compared to Nilgiris honeys, but comparable with the activity from Egyptian clover honey. Tualang and Acacia honeys from Malaysia are able to inhibit the growth of MAR target bacteria using disc diffusion method. Considering the antibacterial activity of honey it was observed that all different honey samples possessed antibacterial activity against target Gram negative and Gram positive pathogenic bacteria as evaluated by disc diffusion and well methods. There were significant differences $(p>0.5)$ between target bacteria using disc diffusion method but there was no significant differences $(\mathrm{p}<0.5)$ with honey type used (Table 2 ).

The well method indicated that all honey samples significantly $(p<0.5)$ inhibited target bacteria, but inhibitory activity varied between bacteria (Table 3 and Fig. 1) with diameter of inhibition between 15.00 and $27.50 \mathrm{~mm}$. The highest inhibitory was shown by H020 from Libya against $S$. aureus $(27.50 \pm 0.70 \mathrm{~mm}), S$. Typhimurium $(19.00 \pm 1.41 \mathrm{~mm})$, B. subtilis $(19.50 \pm 00.70$ $\mathrm{mm})$ and $P$. aeruginosa $(18.50 \pm 2.12 \mathrm{~mm})$ and from H032 from Malaysia against E. coli $(17.00 \pm 0.00 \mathrm{~mm})$. Zainol et al. (2013) tested the antibacterial activity of several Malaysian honeys including Acacia and Tualang and one New Zealand honey (Manuka 18+) using well method against $S$. aureus, E. coli, P.aeruginosa and $B$. cereus; the results varied from 7.59 to $27.35 \mathrm{~mm}$ diameter, the highest inhibitory zone was obtained from Manuka honey against $S$. aureus $(19.81 \mathrm{~mm})$ and $E$. coli
(14.04 mm), comparable inhibitory activity from Tualang honey against $P$. aeruginosa $(16.22 \mathrm{~mm})$ and $B$. cereus $(27.35 \mathrm{~mm})$, while Acacia honey showed the lowest result compared to other samples. In the present study the ability of Al-Seder honey and Acacia honey to kill target bacteria using well method was higher than what observed by Tualang, Acacia and Manuka $18+$ as reported by Zainol et al. (2013) against all MAR target bacteria. The well method tends to give a higher inhibitory activity for all honey compared to disc diffusion method which may due to the direct attach of the tested compound in liquid form to the agar.

In contrast, when the antibacterial activity of the honey samples were evaluated using Nanophotometer assay no significant difference ( $p>0.5)$ was observed for both honey and target pathogens. This method used Nanophotometer (IMPLEN) that reported the number of target bacteria cells (both dead and alive) in the sample. All target pathogen reduced in numbers after $24 \mathrm{~h}$ incubation compared to control (without honey) (Table 4) ranging from 70 to $100 \%$ reduction after $24 \mathrm{~h}$ of incubation as shown by Al-Seder honey, 100\% (H025), Tualang honey, 100\% (H026) and (Acacia honey, 100\% (H030) against $S$. aureus.

In order to confirm the inhibitory potency of honey, the growth of target pathogens were evaluated after $24 \mathrm{~h}$ incubation in microtiter plates. All honey samples showed antibacterial activity against the target pathogenic bacteria evaluated in which growth was inhibited between 64 to $100 \%$ after $24 \mathrm{~h}$ of incubation (Table 5). Honey sample Tualang honey (H026) completely inhibited the growth of $S$. aureus, while Acacia honey (H032) showed the highest activity among the evaluated honey samples. Among the pathogens evaluated, $P$. aeruginosa which was more difficult to be inhibited by all the honey samples. It is interesting to note that this test (microtiter plates) give a different results from above (Agar diffusion, well diffusion and nanophotometer methods). Honey samples showed significant differences $(\mathrm{p}<0.5)$ in antibacterial activity but there was no significant differences $(p>0.5)$ between target pathogens in microtiter plates and similar to the results obtained by nanophotometer method.

Other researchers who evaluated antimicrobial activity from sources other than honey, such as extracts from plants or microbial metabolites have included microdilution assay and microtiter plates in addition to the disc and well methods. The disc diffusion method and well method are the two most commonly used to determine antimicrobial properties of honey (Badawy et al., 2004; French et al., 2005; 
Lusby et al., 2005; Visavadia et al., 2006; Boukraa and Niar, 2007; Boorn et al., 2010; Rajeswari et al., 2010; Kwakman et al., 2011; Mandal and Mandal, 2011). Based on the results obtained in this study it is suggested that either nanophotometeror microtiter plate assay be included for the evaluation of potency of honey as antibacterial agent.

The above methods (Agar diffusion, well diffusion, nanophotometer and microtiter plate methods) did not evaluate the bactericidal effect of honey; thus plating of survivors of target pathogens after treatment with honey was included by using plate count method (Table 6). Acacia honey $\mathrm{H} 032$ and Tualang honey H026 showed total inhibition (survivors $<10$ est.) against all target photogenic bacteria. E. coli was totally inhibited (survivors $<10$ est.) by all tested honey samples except $\mathrm{H} 031$ and H035 which allow recovery of pathogen and reached $10^{5} \mathrm{CFU} / \mathrm{ml}$ after 24 $\mathrm{h}$ incubation. The potency Tualang honey (H026) and Acacia honey (H032) which showed their ability to kill the Multiple Antibiotic Resistant (MAR) bacteria including S. aureus, B. subtilis, S. Typhimurium, E. coli and $P$. aeruginosa suggests their potential to be used as an alternative therapeutic agent in certain medical conditions, particularly wound infection as well as in preservations to control food spoilage.

In most reported study honey was used as it is without heating and at concentrations (w/v) of $15-80 \%$ as used by Mavric et al. (2008); $50 \%$ by Boorn et al. (2010), 17.40, 19.20, 20.80, 23.80\% by Voidarou et al. (2011) and 10, 30, 50, 70, 100\% by Moussa et al. (2012). The antimicrobial activity was dose-dependent, the higher concentrations the greater the activity affecting both Gram-positive and Gram-negative bacteria. Compounds like glucose oxidase, catalase, ascorbic acid, flavonoids, phenolic acids, organic acids, amino acids and proteins were found present in honey in substantial amounts and can be responsible for the activity of honey (Bogdanov et al., 2008; Perez et al., 2007). However, in this study honey samples were heated at $70^{\circ} \mathrm{C}$ for $10 \mathrm{~min}$ and then filtered using $0.45 \mu \mathrm{L}$ membrane filters. Heating at $70^{\circ} \mathrm{C}$ was reported to decrease glucose oxidase but not totally destroyed the enzyme (Kretavicius et al., 2010), whereas hydrogen peroxide activity can be destroyed by heat, light or storage (Bogdanov, 1997). Additionally, all the honey samples were also diluted with deionized water at $200 \mathrm{mg} \mathrm{mL}^{-1}$, a much lower concentration than that used by others and the antibacterial activity was observed. This study suggested that many compounds including heat stable compounds are responsible for the antibacterial activity and cannot be attributed to one or two main compounds present in honey.

\section{CONCLUSION}

The antibacterial activity of honey cannot be confirmed by using one single method. While disc diffusion and/or well diffusion method are useful for initial screening, other methods such as microtiter plates, nanophotometer assay and/or plate count method should be included. To ascertain the potency of honey, the survival of target pathogens after treatment with honey should be carried out as well. This study also confirmed that even at low concentration of honey, it still has the potency to inhibit growth of MAR pathogens and this activity could be contributed by water soluble compounds present in honey. Malaysian honeys namely, Tualang and Acacia tend to give the betterantibacterial activity compared to other honey samples evaluated. This work further supports that honey could be used as antibacterial agent.

\section{ACKNOWLEDGMENT}

The researchers would like to thank the management of Faculty of Science and Technology, Islamic Science University of Malaysia for supporting this work.

\section{REFERENCES}

Aljadi, A.M. and K.M. Yusoff, 2003. Isolation and identification of phenolic acids in Malaysian honey with antibacterial properties. Turk. J. Med. Sci., 33: 229-236.

Aween, M.M., Z. Hassan, B.J. Muhialdin, Y.A. Eljamel and A.S.W. Al-Mabrok et al., 2012a. Antibacterial activity of Lactobacillus acidophilus strains isolated from honey marketed in Malaysia against selected Multiple Antibiotic Resistant (MAR) Gram-positive bacteria. J. Food Sci., 77: 364-371. DOI: 10.1111/j.1750-3841.2012.02776.x

Aween, M.M., Z. Hassan, B.J. Muhialdin, H.M. Noor and Y.A. Eljamel, 2012b. Evaluation on antibacterial activity of Lactobacillus acidophilus strains isolated from honey. Am. J. Applied Sci., 6: 807-817. DOI: 10.3844/ajassp.2012.807.817 
Badawy, O.F.H., S.S.A. Shafii, E.E. Tharwat and A.M. Kamal, 2004. Antibacterial activity of bee honey and its therapeutic usefulness against Escherichia coli O157:H7 and Salmonella typhimurium infection. Rev. Scientif. Tech., 23: 1011-1122. PMID: 15861897

Bauer, A.W., W.M. Kirby, J.C. Sherris and M. Turck, 1966. Antibiotic susceptibility testing by a standardized single disk method. Am. J. Clin. Pathol., 4: 493-496. DOI: 5325707

Bogdanov, S., 1997. Nature and origin of the antibacterial substances in honey. LWT Food Sci. Technol., 30: 748-753. DOI: 10.1006/fstl.1997.0259

Bogdanov, S., T. Jurendic, R. Sieber and P. Gallmann, 2008. Honey for nutrition and health: A review. J. Am. Coll. Nutrit., 27: 677-689. DOI: 10.1080/07315724.2008.10719745

Boorn, K.L., Y.Y. Khor, E. Sweetman, F. Tan and T.A. Heard et al., 2010. Antimicrobial activity of honey from the stingless bee Trigona carbonaria determined by agar diffusion, agar dilution, broth microdilution and time-kill methodology. J. Applied Microbiol., 108: 1534-1543. DOI: 10.1111/j.13652672.2009.04552.x

Boukraa, L. and A. Niar, 2007. Sahara honey shows higher potency against Pseudomonas aeruginosa compared to north Algerian types of honey. J. Medicinal Food, 4: 712-4. DOI: 10.1089/jmf.2006.256

Cooper, R.A., E. Halas, R. Davies, P.C. Molan and K.C. Harding, 2000a. The inhibition of Gram-positive cocci of clinical importance by honey. Proceedings of the 1st World Healing Congress, Sept. 10-13, Melbourne, Australia.

Cooper, R.A., P. Wigley and N.F. Burton, $2000 \mathrm{~b}$. Susceptibility of multiresistant strains of Burkholderia cepacia to honey. Lett. Applied Microbiol., 31: 20-4. DOI: 10.1046/j.1472765x.2000.00756.x

French, V.M., R.A. Cooper and P.C. Molan, 2005. The antibacterial activity of honey against coagulasenegative staphylococci. J. Antimicrobial Chemotherapy, 56: 228-231. DOI: 10.1093/jac/dki193

Hassanain, A.T., A.K. Alyaa and A.J. Karim, 2010. Antimicrobial effect of Malaysian honey on some human pathogens: An in vitro study. Int. Med. J. Malaysia, 9: 15-17.
Kretavicius, J., B. Kurtinaitiene, J. Racys and V. Ceksteryte, 2010. Inactivation of glucose oxidase during heat-treatment de-crystallization of honey. Agriculture, 97: 115-122.

Kwakman, P.H.S., A.A. TeVelde, L. de Boer, C.M.J.E. Vandenbroucke-Grauls and S.A.J. Zaat, 2011. Two major medicinal honeys have different mechanisms of bactericidal activity. Plos One, 6: 1-7. DOI: 10.1371/journal.pone.0017709

Lusby, P.E., A.L. Coombes and J.M. Wilkinson, 2005. Bactericidal activity of different honeys against pathogenic bacteria. Arch. Med. Res., 36: 464-467. DOI: 10.1016/j.arcmed.2005.03.038

Magnusson, J. and J. Schnurer, 2001. Lactobacillus coryniformis subsp.coryniformis Strain Si3 Produces a broad-spectrum proteinaceous antifungal compound. Applied Environ. Microbiol., 67: 1-5. DOI: 10.1128/AEM.67.1.1-5.2001

Mandal, M.D. and S. Mandal, 2011. Honey: Its medicinal property and antibacterial activity. Asian Pacific J. Tropical Biomed., 2: 154-160. DOI: 10.1016/S2221-1691(11)60016-6

Mavric, E., S. Wittmann, G. Barth and T. Henle, 2008. Identification and quantification of methylglyoxal as the dominant antibacterial constituent of Manuka (Leptospermum scoparium) honeys from New Zealand. Molecular Nutrit. Food Res., 52: 483-9. DOI: 10.1002/mnfr.200700282, PMID: 18210383

Mohammed, S.J., 2010. Therapeutic efficacy of Lactobacillus acidophilus against bacterial isolates from burn wounds. North Am. J. Medical Sci., 2: 1947-2714. PMID: 22558572

Molan, P.C., 1997. Honey as an Antimicrobial Agent. In: Bee Products: Properties, Applications and Apitherapy, Mizrahi, A. and Y. Lensky (Eds.), Plenum Press, New York, pp: 27-37.

Moussa, A., D., Noureddine, H.S. Mohamed, M. Abdelmelek and A. Saad, 2012. Antibacterial activity of various honey types of Algeria against Staphylococcus aureus and Streptococcus pyogenes. Asian Pacific J. Tropical Med., 4: 773776. DOI: 10.1016/S1995-7645(12)60141-2

Nasir, N.M., A.S., Halim, K.B., Singh, A.A. Dorai and M. M. Haneef, 2010. Antibacterial properties of tualang honey and its effect in burn wound management: A comparative study. BMC Complementary Alternative Med., 10: 31-31. DOI: $10.1186 / 1472-6882-10-31$ 
Perez, C., M. Pauli and P. Bazerque, 1990. An antibacterial assay by agar well diffusion method. Acta Bio Med. Exp.

Perez, R.A., M.T., Iglesias, E., Pueyo, M. Gonzalez and C. de Lorenzo, 2007. Amino acid composition and antioxidant capacity of Spanish honeys. J. Agric. Food Chem., 55: 360-365. DOI: 10.1021/jf062055b

Rahman, M.M., R. Allan and M.S. Azirun, 2010. Antibacterial activity of propolis and honey against Staphylococcus aureus and Escherichia coli. Afr. J. Microbiol. Res., 4: 1872-1878.

Rajeswari, T., A. Venugopal, C. Viswanathan, L. Kishmu and C.K. Venil et al., 2010. Antibacterial activity of honey against Staphylococcus aureus from infected wounds. Pharmacologyonline, 1: 537-541.

Rozaini, M.Z., A.B.Z. Zuki, M. Noordi, Y. Norimah and A.N. Haki, 2004. The effects of different types of honey on tensile strength evaluation of burn wound tissue healing. Int. J. Applied Res. Vet. Med., 2: 290-296.

Salvatore, V., S. Christian, C. Francesca, S. Vincenzo and S. Carloand et al., 2010. Antibiotic resistance in Staphylococcus aureus and coagulase negative staphylococci isolated from goats with subclinical mastitis. Vet. Med. Int. PMID: 20445785

Subramani, S. and S. Vignesh, 2012. MAR index study and MDR character analysis of a few golden staph isolates. Asian J. Pharmacy Life Sci., 2: 151-154.
Tan, H.T., R.A. Rahman, S.H. Gan, A.S. Halim and S.A. Hassan et al., 2009. The antibacterial properties of Malaysian tualang honey against wound and enteric microorganisms in comparison to Manuka honey. BMC Complementary Alternative Med., 9: 1-8. DOI: 10.1186/14726882-9-34

Taormina, L.R., B.A. Niemara and L.R. Beuchat, 2001. Inhibitory activity of honey against foodborne pathogens as influenced by the presence of hydrogen peroxide and level of antioxidant power. Int. J. Food Microbiol., 69: 217-225. DOI: 10.1016/S0168-1605(01)00505-0

Tumin, N.N., A.A. Halimi, M. Shahjahan, N.J. Rani and M.A. Sattar et al., 2005. Antimicrobial activity of local Malaysian honey. Malaysian J. Pharmaceutical Sci., 3: 1-10.

Visavadia, B.G., J. Honeysett and M.H. Danford, 2006. Manuka honey dressing: An effective treatment for chronic wound infections. Brazil. J. Maxillofacial Surgery, 44: 38-41. PMID: 17113690

Voidarou, C., A. Alexopoulos, S. Plessas, A. Karapanou and I. Mantzourani et al., 2011. Antibacterial activity of different honeys against pathogenic bacteria. Anaerobe, 17: 375-379. DOI: 10.1016/j.anaerobe.2011.03.012

Zainol, M.I., K.M. Yusoff and M.Y.M. Yusof, 2013. Antibacterial activity of selected Malaysian honey. BMC Complementary Alternative Med., 13: 129-129. DOI: 10.1186/1472-6882-13-129 